\title{
Kepemimpinan Kepala Sekolah Perempuan Lembaga Pendidikan Islam Dasar Di Kecamatan Nglegok Kabupaten Blitar
}

\author{
Badrus, ${ }^{1}$ Lilik Sri Wahyuni ${ }^{2}$ \\ Pascasarjana Institut Agama Islam Tribakti Kediri, \\ lilik13rf@gmail.com
}

\begin{abstract}
This study aims to: (1) describe the Leadership of Women's School Principals in Nglegok, Blitar Regency; (2) describing the factors that support and hinder the leadership of women school principals in Nglegok, Blitar Regency. This research is a qualitative research. The research sites are Islamic Elementary Echool "Kreatif Zaid Bin Tsabit", Primary School Ngoran 02, and Integrated Islamic Elementary School Wildan Mukholladun Nglegok Blitar. Resource persons for the study are principals, teachers, and operators. Data collection uses participant observation, interviews, and documentation. Data validity uses triangulation with data sources. Data analysis techniques by data reduction, data presentation, data analysis, drawing conclusions, and verification. The results showed: (1) Leadership of female school principals in Nglegok Sub-District, Blitar Regency had been going well, it was proven that the school principal had carried out several strategic policies. (2) Factors that support the leadership of female school principals in Nglegok District, Blitar Regency include: government policies, technological advances, increased awareness of the potential and existence of women, state recognition of women's potential, human rights enforcement and a democratic system. While the inhibiting factors are rigidity in interpreting the text of religion, feelings of doubt and lack of confidence in some women.
\end{abstract}

Keywords: Leadership, Female Principals

\begin{abstract}
Abstrak
Penelitian ini bertujuan untuk: (1) mendeskripsikan Kepemimpinan Kepala Sekolah Perempuan di Kecamatan Nglegok Kabupaten Blitar; (2) mendeskripsikan faktor-faktor yang mendukung dan menghambat Kepemimpinan Kepala Sekolah Perempuan di Kecamatan Nglegok Kabupaten Blitar. Penelitian ini merupakan penelitian kualitatif. Tempat penelitian di SDI Kreatif Zaid Bin Tsabit, SDN Ngoran 02, dan SDIT Wildan Mukholladun Nglegok Blitar. Narasumber penelitian adalah kepala sekolah, guru, dan operator.Pengumpulan data menggunakan observasi partisipan (pengamatan), wawancara, dan dokumentasi. Keabsahan data menggunakan triangulasi dengan sumber data. Teknik analisis data dengan cara reduksi data, sajian data, analisis data, penarikan kesimpulan, dan verifikasi. Hasil penelitian menunjukkan: (1) Kepemimpinan kepala sekolah perempuan di Kecamatan Nglegok Kabupaten Blitar sudah berjalan dengan baik, terbukti
\end{abstract}


kepala sekolah telah melakukan beberapa kebijakan strategis. (2) Faktor-faktor yang mendukung kepemimpinan kepala sekolah perempuan di Kecamatan Nglegok Kabupaten Blitar meliputi: kebijakan pemerintah, kemajuan teknologi, peningkatan kesadaran terhadap potensi dan eksistensi perempuan, pengakuan negara terhadap potensi perempuan, penegakan HAM serta sistem demokrasi. Sedangkan faktor-faktor yang menghambat yaitu kekakuan dalam menginterpretasikan nash agama, perasaan ragu dan tidak percaya diri pada sebagian perempuan.

Kata Kunci: Kepemimpinan, Kepala sekolah perempuan.

\section{Pendahuluan}

Perempuan mempunyai peranan penting dalam kehidupan bermasyarakat dan dalam pembangunan. Hal ini dapat dirasakan setelah R.A. Kartini mengadakan pergerakkan emansipasi wanita. Keberadaan peran perempuan sebagai pimpinan kini mulai mendapatkan pengakuan. ${ }^{1}$

Departemen

pendidikan nampaknya sudah berupaya menjawab isu tersebut, dengan memberi kesempatan kepada para perempuan untuk menjadi pemimpin secara formal di sekolah-sekolah untuk semua jenjang dan satuan pendidikan. Permendiknas RI nomor 13 tahun 2007 tentang Standar Kepala Sekolah tidak mempermasalahkan apakah yang menjadi kepala sekolah tersebut laki-laki atau perempuan. Standar kepala sekolah yang ditentukan lebih banyak ditekankan pada kemampuan kompetensinya. ${ }^{2}$

1 Eka Mulyani, Gender dalam Tulisan R.A.Kartini Perspektif Pendidikan Islam, Skripsi (Purwokerto: IAIN Purwokerto, 2017).

2 www.mediapendidikan.info $>2010 / 09$. Permendiknas No.13 Th 2007 Standar Kepala Sekolah.Diunduh Tgl 9 April 2019 jam 08:25.
Kepala sekolah sebagai kunci pendorong bagi perkembangan dan kemajuan sekolah serta bertanggung jawab untuk meningkatkan akuntabilitas keberhasilan siswa dan programnya. ${ }^{3}$

Kepemimpinan kepala sekolah merupakan salah satu faktor yang dapat mendorong sekolah untuk dapat mewujudkan visi, misi, tujuan, dan sasaran sekolahnya melalui programprogram yang dilaksanakan dengan perencanaan yang matang.

Meskipun, peran perempuan sebagai kepala sekolah semakin besar, kenyataannya di kecamatan Nglegok Kabupaten Blitar dari 50 Sekolah Dasar dan Madrasah Ibtidaiyah hanya 11 orang Kepala Sekolah perempuan. Hal ini menunjukkan bahwa peran kepemimpinan kepala sekolah perempuan di Nglegok masih kurang. ${ }^{4}$

Berdasarkan hasil pengamatan awal, kepala sekolah perempuan memiliki potensi dan kemampuan yang

3 Purwanti,dkk. Kepemimpinan Kepala Sekolah dalam Meningkatkan Kompetensi Guru pada SMPN 2 Simeuleu Timur.Jurnal Ilmiah Dikdaktika XIV(2),,2014: 390-400.

4 Dapo.dikdasmen.kemdikbud.go.id $>$ Data Sekolah Kecamatan Nglegok-Dapodikdasmen. 2018/2019. Diunduh Tgl 9 April 2019 jam 09:02 
tidak kalah dengan laki-laki dalam meningkatkan prestasi di sekolah yang mereka pimpin. Beberapa kepala sekolah itu diantaranya adalah Kepala Sekolah SDI Kreatif Zaid Bin Tsabit, SDN Ngoran 02, dan SDIT Wildan Mukholadun. Sekolah tersebut dipimpin oleh kepala sekolah perempuan yang memiliki pencapaian prestasi yang baik.

\section{Metode}

Penelitian ini menggunakan pendekatan kualitatif multi situs berperspektif feminisme. ${ }^{5}$ Karakteristik peneliti meneliti dua atau lebih subjek, latar atau tempat penyimpanan data. Kasus yang diteliti dalam penelitian ini adalah Kepemimpinan kepala sekolah perempuan dalam menentukan kebijakan lembaga pendidikan, bias psikologi perempuan, dan gaya kepemimpinan kepala sekolah perempuan di tiga lembaga pendidikan yang memiliki karakter berbeda.

\section{Kajian Teoritk \\ Kepemimpinan}

Kepemimpinan mencakup bagaimana upaya mempengaruhi, mendorong, memfasilitasi orang lain dalam rangka pencapaian tujuan dengan menggunakan cara-cara tertentu. Dalam hal ini kepemimpinan menuntut kemampuan tertentu untuk menyelaraskan keinginan dan ekspektasi pengikut dan pengikut utama studi multi kasus adalah apabila

secara sukarela bersedia mengikuti si pemimpin dengan antusias dan dedikasi, dimana persyaratan ini tidak harus ada dalam administrasi dan manajemen. ${ }^{6}$ Kepemimpinan juga sebagai aktivitas untuk mempengaruhi orang-orang supaya diarahkan untuk mencapai tujuan organisasi. ${ }^{7}$

Berdasarkan Peraturan Menteri Pendidikan dan Kebudayaan (Permendikbud) Republik Indonesia Nomor 6 Tahun 2018 tentang Penugasan Guru sebagai kepala sekolah sebagai berikut:

1. memiliki kualifikasi akademik paling rendah sarjana (S-1) atau diploma empat (D-IV) dari perguruan tinggi dan programs tudi yang terakreditasi paling rendah B;

2. memiliki sertifikat pendidik;

3. bagi Guru PNS memiliki pangkat paling rendah Penata, golongan ruang III/c;

4. pengalaman mengajar paling sedikit 6 (enam) tahun menurut jenis dan jenjang sekolah masing masing, kecuali diTK/TKLB memiliki pengalaman mengajar sekurangkurangnya 3 (tiga) tahun di TK/TKLB;

5. memiliki hasil penilaian prestasi kerja guru dengan sebutan paling rendah "Baik" selama 2 (dua) tahun terakhir;

6. memiliki pengalaman manajerial dengan tugas yang relevan dengan

Teori. (Surabaya: Jenggala Pustaka Utama. 2017) h: 2.

7 Thoha,Miftah. Kepemimpinan dalam Suatu Pendekatan Edisi Revisi. (Bandung: PT Remaja Rosdakarya. 2010), h. 57

6 Susilo,Suko. dan Dwi Tjahjadi, Denny.Kepemimpinan dalam Perspektif Beberapa 
fungsi sekolah paling sedikit 2(dua) tahun;

7. sehat jasmani, rohani, dan bebas NAPZA berdasarkan surat keterangan dari rumah sakit Pemerintah;

8. tidak pernah di kenakan hukuman di siplin sedang dan/atau berat sesuai dengan ketentuan peraturan perundang- undangan;

9. tidak sedang menjadi tersangka atau tidak pernah menjadi terpidana; dan

10. berusia paling tinggi 56 (lima puluh enam) tahun pada waktu pengangkatan pertama sebagai Kepala Sekolah. ${ }^{8}$

Menurut Thoha dalam buku Kepemimpinan dalam Manajemen terdapat beberapa teori kepemimpinan diantaranya:

\section{Teori Sifat (Trait Theory)}

Ada empat sifat yang berpengaruh terhadap keberhasilan kepemimpinan, yaitu: kecerdasan, kedewasaan dan kekuasaan hubungan sosial, motivasi diri dan dorongan berprestasi, sikap-sikap hubungan kemanusiaan.

\section{Teori Kelompok}

Teori ini beranggapan bahwa kelompok bisa mencapai tujuantujuannya, harus terdapat suatu pertukaran yang positif diantara pemimpin dan pengikut-pengikutnya.

3. Teori Situasional

Teori ini mengemukakan bahwa kepemimpinan dipengaruhi situasisituasi yang ada di sekitarnya.

8 https://www.websiteedukasi.com>Info $\stackrel{\infty}{\infty}$ Guru.11 Mei 2018.Permendikbud No.6 Tahun $\mp$ 2018. Persyaratan Menjadi Kepala Sekolah Tahun 2018.

\section{Teori Jalan Kecil - Tujuan}

Teori ini menggunakan kerangka teori motivasi. Mereka beranggapan bahwa perilaku pemimpin akan bisa menjadi faktor motivasi terhadap bawahan, jika perilaku itu dapat memuaskan.

\section{Teori Social Learning}

Merupakan suatu teori yang dapat memberikan suatu model yang menjamin kelangsungan, interaksi timbal balik antara pemimpin lingkungan dan perilakunya sendiri. ${ }^{9}$

Berdasarkan uraian tentang teori kepemimpinan tersebut di atas dapat disimpulkan bahwa kepemimpinan adalah kemampuan yang dimiliki seseorang dalam mempengaruhi orang lain untuk mau bekerja sama agar mau melakukan tindakan dan perbuatan dalam mencapai tujuan bersama.

\section{Kepemimpinan Kepala Sekolah}

Berdasarkan uraian kepemimpinan di atas kepemimpinan dalam organisasi sekolah secara umum sama. Kepala Sekolah adalah pemimpin sekaligus manajer yang harus mengatur, memberi perintah sekaligus mengayomi bawahannya yaitu para guru dan karyawan dalam menyelesaikan masalah-masalah yang timbul.

Pengertian kepala sekolah menurut Wahjosumidjo adalah kepala sekolah adalah seorang tenaga fungsional guru yang diberi tugas untuk memimpin suatu

9 Thoha,Miftah.Kepemimpinan dalam Manajemen.(Jakarta:Rajagrafindo Persada. 2006) h. 12. 
sekolah dimana diselenggarakan proses belajar mengajar atau tempat dimana terjadi interaksi antara guru yang memberi pelajaran dan murid yang menerima pelajaran..$^{10}$

Berdasarkan beberapa pengertian di atas dapat disimpulkan bahwa kepala sekolah adalah seorang guru yang mempunyai kemampuan untuk memimpin dan mengelola segala sumber daya yang ada pada suatu sekolah sehingga dapat didayagunakan secara maksimal untuk mencapai tujuan bersama.

Kepemimpinan Kepala Sekolah bisa diartikan sebagai kemampuan Kepala Sekolah dalam mempengaruhi, menggerakkan dan mengarahkan warga sekolah agar mau dan mampu bekerja dan berperan serta dalam mencapai tujuan sekolah yang sudah ditetapkan.

Menurut Mulyasa, kepemimpinan kepala sekolah merupakan salah satu faktor yang dapat mendorong sekolah untuk mewujudkan visi, misi, tujuan dan sasaran sekolahnya melalui programprogram yang dilaksanakan secara terencana dan bertahap. Pendapat tersebut di atas mengandung arti bahwa kepala sekolah dituntut untuk mempunyai kemampuan manajemen dan kepemimpinan yang memadai agar mampu mengambil inisiatif untuk meningkatkan mutu sekolah. kepala sekolah harus melakukan perannya sebagai pimpinan dengan menjalankan fungsi: Kepala sekolah sebagai educator (pendidik), manajer, administrator, supervisor, leader (pemimpin), inovator, motivator. ${ }^{11}$

Dalam hal ini kepala sekolah bertugas melaksanakan fungsi kepemimpinan, baik fungsi yang berhubungan dengan pencapain tujuan pendidikan maupun penciptaan iklim sekolah yang kondusif bagi terlaksananya proses belajar mengajar secara efektif dan efisien. Kepala sekolah yang berhasil apabila memahami keberadaan sekolah sebagai organisasi yang kompleks dan unik, dan mampu melaksanakan peranan kepala sekolah sebagai seorang yang diberi tanggung jawab untuk memimpin sekolah.

Kepemimpinan perempuan pada awalnya menuai kontroversi, tetapi jika kita kembali kepada pada masa Rasulullah masih hidup, Siti Aisyah mampu meriwayatkan 2210 hadits dan mengalahkan kalangan sahabat Nabi laki-laki. Mengenai argumen yang menyatakan bahwa perempuan memiliki kemampuan fisik yang lemah memang demikian halnya. Namun, kelemahan itu tidak akan terlalu berpengaruh apabila ditunjang oleh fasilitas yang memadai. Berbagai fasilitas transportasi, komunikasi, dan manajemen yang canggih akan dapat menutupi kelemahan perempuan di bidang ini. Hal ini sekaligus merupakan faktor yang menutupi kekhawatiran banyak banyak

11 Mulyasa ,E. Menjadi Kepala Sekolah Profesional: Dalam Konteks Menyukseskan MBS dan KBK. (Bandung: PT. Remaja Rosda Karya. 2009):h.90. 
orang tentang ketidakmampuan perempuan dalam menata mental spiritualnya. Pada akhirnya melalui konsep keseteraan gender, jika seorang perempuan memiliki kemampuan untuk menjabat pimpinan, maka di pos kepemimpinan mana pun diperkenankan oleh hukum Islam. Berdasarkan pada teori implisit kepemimpinan yang efektif membutuhkan keterampilan antar pribadi yang kuat, perhatian untuk membangun hubungan yang kooperatif dan mempercayai, dan menggunakan prilaku yang secara tradisonal dipandang sebagai feminim(misalnya mendukung, mengembangkan, memberi kewenangan).

Dibandingkan dengan pria, perempuan lebih memperhatikan pembangunan konsensus, keikutsertaan dan hubungan antar pribadi. Dan para pemimpin perempuan lebih bersedia mengembangkan dan memelihara bawahan dan berbagai kekuasaan dan informasi dengan mereka. Saat persyaratan peran bagi jenis posisi manajerial berbeda itu telah diidentifikasi, para manajer pria lebih efektif dalam posisi yang membutuhkan keterampilan tugas yang kuat, dan manajer perempuan lebih efektif dalam posisi yang membutuhkan keterampilan antar pribadi yang kuat. Jadi dapat disimpulkan bahwa sesungguhnya antara pria dan perempuan sama-sama memiliki potensi dalam kepemimpinannya.

\section{Faktor-Faktor}

\section{Kepemimpinan Perempuan)}

a. Kebijakan yang memberi peluang kepada perempuan untuk berkiprah sebagai hasil perjuangan dari kaum yang concern mengangkat nasib, harkat, derajat, dan martabatkaum perempuan, meskipun belum mencapai optimal, seperti memperjuangkan quota $30 \%$ untuk keterwakilan perempuan di lembaga legislatif.

b. Kemajuan teknologi yang sangat berperan membantu meringankan tugas-tugas domestik maupun tugas publik perempuan, sehingga kaum perempuan yang terlibat di dalamnya tidak perlu terlalu mengandalkan otot dan mengerahkan energi berlebihan seperti sebelunya.

c. Terjadi peningkatan kesadaran terhadap potensi dan eksistensi perempuan secara berangsur-angsur pada sebagian kaum laki-laki maupun perempuan, yang memberi suasana kondusif bagi kaum perempuan untuk dapat berkiprah secara lebih luas di masyarakat.

d. Terdapat pengakuan negara secara berangsur-angsur terhadap potensi para perempuan dalam berbagai bidang.

e. Desakan ideologi dunia yang terus menggulirkan penegakan HAM serta demokratisasi.

f. Berkembangnya media masa yang mengekspos keberhasilan perempuan dalam pembangunan, sehingga berdampak positif mendorong dan memotivasi kaum perempuan untuk 
mengembangkan kemampuan diri melalui pendidikan sekolah maupun luar sekolah.

g. Keberhasilan mengontrol fungsi reproduksi dengan cara berKB, sehingga banyak waktu perempuan untuk ikut terlibat dalam pembangunan.

h. Terdapat sosok model perempuan sukses yang memotivasi perempuan untuk mengikuti jejak kesuksesannya.

\section{Faktor yang Memperlemah Potensi} Kepemimpinan Perempuan

a. Masih terdapat kekakuan dalam menginterpretasikan nash agama berkaitan dengan kepemimpinan perempuan yang hanya berdasarkan tekstual sehingga acapkali berbenturan secara kontekstual.

b. Masih kuat keyakinan masyarakat atas stereotype perempuan yang disosialisasikan dalam pengasuhan anak secara turun temurun.

c. Terdapat kekhawatiran kaum lakilaki tersaingi oleh kaum perempuan.

d. Ada perasasaan ragu dan tidak percaya diri pada sebagian perempuan.

e. Terdapat ekses negatif dari perempuan yang berkiprah di arena publik, terutama perempuan yang telah berkeluarga.

f. Akses perempuan terdapat posisi jabatan dan pekerjaan terbatas.

12 Dwi Saputri, Arista. Kepemimpinan Kepala Sekolah Perempuan dalam Menentukan Kebijakan Lembaga Pendidikan. (Tulungagung: STAIN Tulungagung. 2013),h. 22. g. Dominasi laki-laki secara hitoris dan politis.

h. Ideologi dan suasana kerja yang memihak pada kepentingan laki-laki.

i. Tradisi historis, tidak ada atau minimnya pengalaman dan keterlibatan perempuan dalam kepemimpinan masa lalu.

j. Sistem pemilihan calon pemimpin yang belum fair dan kondusif, sehingga menghambat perempuan masuk daftar calon pemimpin atau terpilih.

k. Mitos kuat bahwa pemimpin harus perkasa yakni laki-laki.

1. Minimnya support terhadap kandidat perempuan, bahkan dari perempuan itu sendiri.

m. Masyarakat dan perempuan sendiri sulit memisahkan antara karir dan arena publik dan peran tradisional dalam lingkungan keluarga dan lingkungan sosial, khususnya dalam kepemimpinan level tinggi. ${ }^{12}$

\section{Wawasan Gender dalam Pendidikan dan Psikologi}

Nasiruddin Umar menjelaskan bahwa konsep cultural yang berupaya membuat perbedaan dalam hal peran, perilaku, mentalitas dan karakter emosional antara laki-laki dan perempuan yang berkembang dimasyarakat. ${ }^{13}$ H. $\quad$ T. Wilson mengartikan jender sebagai suatu dasar untuk menentukan perbedaan sumbangan laki-laki dan perempuan

13 Nasiruddin, Umar. Argumen Kesetaraan Jender Perspektif al-Qur'an. (Jakarta: Paramadina, 1999).h.37 
pada kebudayaan dan kehidupan kolektif yang sebagai akibatnya mereka menjadi laki-laki dan perempuan. ${ }^{14}$

Berdasarkan pengertian diatas dapat disimpulkan bahwa gender adalah perbedaan laki-laki dari segi sosial budaya dalam hal peran, mentalitas, karakter emosional yang berkembang dikehidupan sosial masyarakat.

Gender adalah bentukan sosial dan budaya, maka bias yang berujung pada diskriminasi gender tentulah datang dari konteks budaya dan sosial. Bias dan diskriminasi yang sering diatasnamakan Islam sebenarnya lebih banyak datang dari persoalan konteks dan budaya. Maka kita perlu memperhatikan konteks sosial, politik dan budaya masyarakat Arab saat Al Qur'an turun. Saat ini menjadi seorang pemimpin bukan hanya didominasi oleh kaum pria saja, pemimpin sekarang ini sudah banyak bermunculan pemimpin perempuan.

\section{a. Bias Psikologi Perempuan}

Banyak orang memandang Feminitas dan maskulinitas sebagai citra yang bersifat internal dan menetap. Sebenarnya hal ini merupakan produk budaya yang dinamis dan berkembang. Maka pencitraan perempuan dan lakilaki berdasarkan gender berbeda antara satu budaya dengan budaya lain, dan berbeda antar waktu dan tempat. Beberapa bias dalam psikologi perempuan antara lain sebagai berikut:

$\begin{array}{ccc}\text { Pertama } & \text { Psikologis } & \text { perempuan } \\ \text { dipandang } & \text { dependen, } & \text { berwatak }\end{array}$

15 Nurrachman, Nani. dan Imelda Bachtiar. Psikologi Perempuan:Pendekatan Konstekstual mengasuh dan merawat. Kedua Psikologis perempuan selalu mengalah, menyetujui, menyesuaikan diri dan menyenangkan orang lain. Ketiga psikologis perempuan itu emosional dan mudah menangis. Keempat Psikologis perempuan yang penakut dan sensitif. Kelima psikologis perempuan yang lemah dan tidak berprestasi. Keenam Psikologis perempuan yang mudah terpengaruh dan mudah dibujuk untuk mengubah keyakinannya. Ketujuh Psikologis perempuan lebih sensitif terhadap perilaku non verbal. Kedelapan, psikologi perempuan lebih ekpresif. ${ }^{15}$

\section{b. Kebijakan Pendidikan}

Kebijakan pendidikan merupakan proses dimana suatu pertimbangan harus diambil dalam rangka pelaksanaan pendidikan yang bersifat melembaga, bersifat umum dan dapat dijadikan sebagai pedoman dalam pengambilan keputusan pendidikan. Penjelasan tersebut juga menunjukan bahwa kebijakan pendidikan diarahkan untuk pengembangans egala sumberdaya pendidikan yang ada guna mencapai tujuan pendidikan, serta pengembang seluruh warga sekolah melaui berbagai kegiatan yang berhubungan dengan pengembangan dan keterampilan demi peningkatan kualitas kognitf, afektif dan psikomotorik demi tercapainya sekolah yang efektif dan bermutu. Tahap-tahap yang harus dilewati agar suatu kebijakan dapat disusun dan dilaksanakan dengan baik yaitu: penyusunan agenda,

Indonesia. (Jakarta: Penerbit Universitas Atma Jaya. 2011), h. 29 
Perencanaan kebijakan, Pelaksanaan kebijakan,dan evaluasi kebijakan. ${ }^{16}$

\section{Pembahasan}

\section{Kepemimpinan Kepala Sekolah Perempuan Di Kecamatan Nglegok Kabupaten Blitar}

Kepemimpinan kepala sekolah perempuan di Kecamatan Nglegok Kabupaten Blitar dalam mempengaruhi, menggerakkan, dan mengarahkan warga sekolah agar mau dan mampu bekerja dan berperan serta dalam mencapai tujuan sekolah yang sudah ditetapkan dalam kepemimpinannya peneliti menemukan:

\section{Kebijakan Kepala Sekolah}

Pelaksanaan yang dilakukan oleh ketiga lembaga yaitu:

a. Pengembangan Kompetensi Lulusan (Kompetensi Lulusan Akademik dan non akademik) dengan nilai yang bagus dan prestasi yang membanggakan, serta karakter yang unggul.

b. Pengembangan Kurikulum(K-13) dengan diadakan workshop peningkatan inovasi sumber pembelajaran dan bahan referensi pembelajaran.

c. Pengembangan Proses Pembelajaran yang dilaksanakan yaitu: pemenuhan persiapan pembelajara(PSB) dengan melaksanakan penerimaan siswa baru, pemenuhan pelaksanaan pembelajaran dengan melengkapi administrasi guru kelas, peningkatan proses pembelajaran dengan monitoring dan supervisi, pemenuhan fasilitas pembelajaran dan penilaian dengan melengkapi buku sumber belajar guru, pemenuhan alat olah raga dengan melengkapi alat olah raga, pemenuhan alat peraga dengan melengkapi alat-alat peraga, home visit dengan melakukan kunjungan ke rumah siswa yang bermasalah, dan pembelian /pengadaan komputer dengan penambahan komputer.

d. Pengembangan sistem Penilaian dengan meningkatan frekuensi ulangan harian, peningkatan pelaksanaan UTS, pengembangan materi UAS, pengembangan materi UKK, dan program remidial.

e. Pengembangan Pendidik dan Tenaga Kependidikan dengan meningkatan kompetensi tenaga pendidik dan kependidikan dengan mengikuti berbagai diklat dan pelatihan yaitu di dalam kecamatan dengan diklat kepemimpinan, Bintek manajemen pengelolaan sekolah, KKG tingkat gugus, Diklat KTI/ PTK, Diklat media pembelajarn, Bintek K-13, dan Bintek Manajemen pengelolaan BOS; Di luar kecamatan dengan diklat kepemimpinan, Bintek manajemen pengelolaan sekolah, diklat peningkatan profesi guru.

f. Pengembangan sarana dan Prasarana Sekolah dengan pemenuhan sarana dan prasarana minimal(pengadaan media pembelajaran, pengadaan

16 Riant Nugroho D,Kebijakan Publik: Formulasi, Implementasi, dan Evaluasi, (Jakarta: PT Alex Media Komputindo.2003): h. 179. 
mebeulair, pengadaan papan tulis), pemenuhan sarana lainnya (pengadaan perangkat computer, pengadaan perangkat internet, pengadaan multi media), pemeliharaan dan perbaikan dengan melaksanakan pemeliharaan dan perbaikan sarana dan prasarana sekolah( pengecatan \& pelaburan, perbaikan pintu / jendela, pebaikan atap \& lantai, perbaikan pagar/ halaman, perbaikan mebeulair).

g. Pengembangan Manajemen sekolah dengan mengadakan kegiatan rapat dinas yang meliputi pleno/sosialisasi RKAS, rapat awal tahun pelajaran/pembagian tugas, rapat pembinaan, rapat semester, rapat UN/UAS, rapat kenaikan kelas, rapat kelulusan, rapat rutin/bulanan dan rapat komite sekolah dengan guru kelas/pendidik, tenaga kependidikan, dan agar seluruh komponen sekolah paham dengan tugas dan jobdisnya. Sehingga kegiatan dapat berjalan dengan lancar dan baik. Selain itu saya, beberapa tenaga pendidik, dan komite melaksanakan perjalanan dinas dalam dan luar kecamatan(Perjalanan dinas kepala sekolah/komite sekolah, perjalanan dinas guru), menyiapkan akreditasi sekolah (membuat perencanaan, melaksanakan sosialisasi, melengkapi keperluan akreditasi, melaksanakan akreditasi sekolah, mengevaluasi hasil akreditasi sekolah), menyelenggarakan pengelolaan BOS (mendistribusikan keuangan sesuai dengan yang telah dibuat, membuat pelaporan pertanggungjawaban kegiatan).

h. Pembinaan Kesiswaan/Ekstrakurikuler dengan melakukan kegiatan antara lain kegiatan siswa(secara rutin yaitu Perencanaan kegiatan, Pelaksanaan kegiatan, Evaluasi kegiatan, Pelaporan), Latihan Rutin (Perencanaan kegiatan, Pelaksanaan kegiatan, Evaluais kegiatan, Pelaporan), Pelaksanaan HUT Pramuka (Perencanaan kegiatan, Pelaksanaan kegiatan, Evaluasi kegiatan, Pelaporan), Pelantikan (Perencanaan kegiatan, Pelaksanaan kegiatan, Evaluasi kegiatan, Pelaporan), Pramuka dilaksanakan secara rutin (Perencanaan kegiatan, Pelaksanaan kegiatan, Evaluais kegiatan, Pelaporan), olah raga secara rutin melakukan Perencanaan kegiatan, Pelaksanaan kegiatan, Evaluasi kegiatan, dan Pelaporan), keagamaan meliputi Shalat Berjamaah, mengaji(Baca tulis Alquran), puasa senin kamis, SBQ, kaligrafi, khotmil Qur'an, Pesantren kilat, dan seni.

i. Budaya dan Lingkungan sekolah dengan mengembangkan budaya bersih, pemeliharaan sistem sanitasi \& Drainase, peningkatan kerjasama dengan intansi lain yang relevan.

j. Pendidikan Karakter dan Budaya Bangsa/Kewirausahaan dengan mengadakan bintek kurikulum Pendidikan berkarakter, administrasi penunjang kurikulum dengan melengkapi administrasi penunjang kurikulum pendidikan berkarakter. 


\section{Evaluasi Kebijakan Kepala Sekolah} Perempuan

Ketiga lembaga ini menggunakan forum rapat untuk melakukan evaluasi. Di lembaga pertama rapat diadakan dua kali dalam satu tahun Evaluasi dilakukan dalam bentuk supervisi baik internal maupun eksternal. Evaluasi internal dilakukan dengan cara supervisi ke kelaskelas secara acak atau random.

Sedangkan evaluasi di lembaga kedua dilakukan dalam bentuk rapat secara internal setiap tiga bulan sekali dan dihadiri oleh seluruh tenaga pendidik. Untuk lembaga ketiga, rapat diadakan setiap hari senin, evaluasi tiap akhir semester, dan kenaikan kelas. Dalam rapat ini masing-masing penanggung jawab melaporkan hasil kegiatan yang telah dilakukan selama tiga bulan kemarin.

2. Bias Psikologi Kepala Sekolah Perempuan di SDI Kreatif Zaid Bin Tsabit, SDN Ngoran 02, dan SDIT Wildan Mukholladun

Anggapan psikologi perempuan itu lemah, tidak berprestasi dan emosional tidaklah benar. Perempuan bisa juga besikap tegas. Seperti Kepala sekolah di lembaga pertama memiliki komitmen yang kuat, berani mengambil resiko dan tidak mudah menyerah. Dan tidak menutup kemungkinan bahwa seorang perempuan bisa menjadi pemimpin yang handal dan mampu berprestasi. Itu dibuktikan dengan banyaknya prestasi yang telah diperoleh beliau untuk pribadi maupun lembaga.

$$
\text { Sedangkan Psikologi seorang }
$$
perempuan dalam kepemimpinan kepala sekolah perempuan di lembaga kedua tidak menunjukkan bahwa anggapan terhadap seorang perempuan itu lemah, cengeng dan mudah terpengaruh benar adanya. Terbukti, Beliau mampu menjalankan amanah sebagai pemimpin dengan sebaik-baiknya. Cara yang ditempuh oleh Beliau adalah dengan menempatkan diri sesuai dengan situasi dan kondisi dimana Beliau berada.

\section{Gaya Kepemimpinan Kepala}

\section{Sekolah Perempuan}

Gaya kepemimpinan yang diterapkan oleh sekolah pertama adalah gaya kepemimpinan situasional. Untuk sekolah kedua dengan gaya kepemimpinan kharismatik. Dan sekolah ketiga dengan gaya kepemimpinan demokratis.

\section{a. Faktor-faktor Yang Mendukung dan Menghambat Kepemimpinan Kepala Sekolah Perempuan di Kecamatan Nglegok Kabupaten Blitar}

Faktor yang mendukung meliputi: kebijakan pemerintah yang memberi peluang kepada perempuan untuk berkiprah sebagai hasil perjuangan dari kaum yang concern mengangkat nasib, harkat, derajat, dan martabat kaum perempuan; kemajuan teknologi yang sangat berperan membantu meringankan tugas-tugas domestik maupun tugas publik perempuan, terjadi peningkatan kesadaran terhadap potensi dan eksistensi perempuan secara berangsurangsur pada sebagian kaum laki-laki maupun perempuan, yang memberi suasana kondusif bagi kaum perempuan untuk dapat berkiprah secara lebih luas di masyarakat, pengakuan negara secara berangsur-angsur terhadap potensi para 
perempuan dalam berbagai bidang, termasuk pendidikan; desakan ideologi dunia yang terus menggulirkan penegakan HAM serta demokratisasi;b erkembangnya media masa yang mengekspos keberhasilan perempuan dalam pembangunan, sehingga berdampak positif mendorong dan memotivasi kaum perempuan untuk mengembangkan kemampuan diri melalui pendidikan sekolah maupun luar sekolah; keberhasilan KB, sehingga banyak waktu perempuan untuk ikut terlibat dalam pembangunan; sosok model perempuan sukses yang memotivasi perempuan untuk mengikuti jejak kesuksesannya; banyaknya prestasi yang diperoleh saat perempuan menjadi pemimpin; dukungan keluarga dan teman sehingga memotivasi seorang perempuan menjadi pemimpin; dan tingkat pendidikan yang setara/melebihi kaum laki-laki.

Faktor-faktor yang menghambat kepemimpinan kepala sekolah perempuan di kecamatan Nglegok Kabupaten Blitar yaitu masih terdapat kekakuan dalam menginterpretasikan nash agama; masih kuat keyakinan masyarakat atas pola pengasuhan anak secara turun temurun; terdapat kekhawatiran kaum laki-laki tersaingi oleh kaum perempuan; perasaan ragu dan tidak percaya diri pada sebagian perempuan; terdapat ekses negatif dari perempuan yang berkiprah diarena publik, akses perempuan terhadap posisi jabatan dan pekerjaan terbatas; dominasi laki-laki; ideologi dan suasana kerja yang memihak pada kepentingan laki-laki; tradisi historis, tidak ada atau minimnya pengalaman dan keterlibatan perempuan dalam kepemimpinan masa lalu; sistem pemilihan calon pemimpin yang belum fair dan kondusif,; mitos kuat bahwa pemimpin harus perkasa yakni laki-laki; Minimnya support terhadap kandidat perempuan; masyarakat dan perempuan sendiri sulit memisahkan antara karir dan arena publik dan peran tradisional dalam lingkungan keluarga dan lingkungan sosial; kurangnya sarana dan prasarana; serta kurangnya dana.

\section{Kesimpulan}

Berdasarkan hasil penelitian tentang kepemimpinan kepala sekolah perempuan di Kecamatan Nglegok Kabupaten Blitar, maka peneliti dapat mengambil kesimpulan sebagai berikut:

1. Kepemimpinan kepala sekolah perempuan di Kecamatan Nglegok Kabupaten Blitar sudah berjalan dengan baik. Untuk bias psikologi perempuan yang selama ini dianggap lemah, tidak berprestasi dan emosional dalam kepemimpinan perempuan di lembaga pendidikan tidak benar. Sedangkan gaya kepemimpinan yang diterapkan oleh kepala sekolah SDI Kreatif Zaid Bin Tsabit adalah gaya kepemimpinan situasional, untuk SDN Ngoran 02 kepala sekolah mempunyai gaya kepemimpinan kharismatik, dan SDIT Wildan Muikholladun dengan gaya kepemimpinan demokratis.

2. Faktor-faktor yang mendukung kepemimpinan kepala sekolah perempuan di Kecamatan Nglegok Kabupaten Blitar meliputi: kebijakan pemerintah, kemajuan teknologi, terjadi peningkatan kesadaran 
terhadap potensi dan eksistensi perempuan secara berangsur-angsur pada sebagian kaum laki-laki maupun perempuan, terdapat pengakuan negara secara berangsur-angsur terhadap potensi para perempuan dalam berbagai bidang.

3. Sedangkan faktor-faktor yang menghambat kepemimpinan kepala sekolah perempuan di Kecamatan Nglegok Kabupaten Blitar yaitu masih terdapat kekakuan dalam menginterpretasikan nash agama berkaitan dengan kepemimpinan perempuan yang hanya berdasarkan tekstual sehingga acapkali berbenturan secara kontekstual, masih kuat keyakinan masyarakat atas stereotype perempuan yang disosialisasikan dalam pengasuhan anak secara turun temurun. 


\section{Daftar Pustaka}

Apriyanto,Teguh. (2007) Pengaruh Kepemimpinan Kepala Sekolah dan Iklim Organisasi. Erlangga, Jakarta.

Arikunto, Suharsimi. (2006) Prosedur Penelitian Suatu Pendekatan Praktis, Edisi Revisi VI. PT.Reineka Cipta, Jakarta.

Andrew J. Dubrin. (2006) The Complete Ideal's Guides to Leadership $2^{\text {nd }}$ Edition yang dialih bahasa oleh Tri Wibowo BS.:Prenada, Jakarta.

A.Tabrani Rusyan,dkk. (2000) Pendekatan dalam Proses Belajar Mengajar. Remaja Karya, Bandung.

Al Qur'an terjemah Revisi Depag.(1989). CV.Toha Putra, Semarang.

Dunn, William N. (2003) Pengantar Analisis Kebijakan Publik. Gajah Mada University Press, Jogjakarta.

Danim, Sudarwan. (2010) Pengantar Studi Penelitian Kebijakan Alfabeta, Bandung.

Dwi Saputri, Arista. (2013) Kepemimpinan Kepala Sekolah Perempuan dalam Menentukan Kebijakan Lembaga Pendidikan. STAIN Tulungagung, Tulungagung. 